\title{
59. Polisiye romanda doğa ve mit: Baztán Üçlemesi ${ }^{1}$
}

\section{Zeliha DURAN2}

APA: Duran, Z. (2021). Polisiye romanda doğa ve mit: Baztán Üçlemesi. RumeliDE Dil ve Edebiyat Araştırmaları Dergisi, (23), 935-952. DOI: 10.29000/rumelide.949942.

\section{$\ddot{\mathbf{O} z}$}

İspanyol edebiyatında polisiye roman, diğer ülke edebiyatlarında olduğu gibi erkek yazarların kaleminden doğar ve erkek bakış açısıyla gelişimini sürdürür. XX. yüzyılın ortalarında tam anlamıla edebiyat dünyasında tanınırlık kazanır. 1970'li yıllarda önce siyasi bir kimlikle varlık gösterir. 1975 yllında Franco'nun ölümünün ardından kadın yazarlar da polisiye roman türünde eserler vermeye başlarlar. 1980'li yıllarda feminist hareketin İspanya'da etkinliğini arttırmasıyla birlikte polisiye roman türünün cinsiyetçi yapısı kadın yazarlar tarafından kurgulanan kadın dedektiflerle kırılmaya başlar. Bu çalışma, İspanyol yazar Dolores Redondo tarafından 2013-2014 yılları arasında yazılan Baztán Üçlemesi üzerinden polisiye roman türünün süregelen cinsiyetçi yapısının kırılma noktalarını incelemektedir. El Guardián Invisible (2013), Legado en los Huesos (2013) ve Ofrenda a la Tormenta (2014) romanlarından oluşan Baztán Üçlemesi, Bask mitolojik figürleriyle beslenerek kurgulanır. Üçlemenin kahramanı kadın dedektif Amaia Salazar, Bask mitolojisindeki dişi tanrıça Mari/Maya ile özdeşleştirilir. Bu özdeşleşimin yanı sıra anne rahmine dönüşe işaret eden mağara, orman ve nehir alegorileri anlatı boyunca tekrarlanır. Kültürel ekofeminist bir yaklaşımla Batı düşünce sisteminin temelini oluşturan ikilikler ağındaki değerler sorgulamaya açılır. Kadın ve doğa arasında kurulan bağ onaylanarak kadının doğaya benzeşimi annelik üzerinden yüceltilir. Anaerkilliğe işaret edilerek toprak ana metaforu canlandırılır ve kadın kimliği yeniden tanımlanır. Böylece kurgulanan kadın dedektif üzerinden İspanyol edebiyatında polisiye romanın süregelen cinsiyetçi yapısı kırılır ve tür, yeniden yazıma uğrar.

Anahtar kelimeler: İspanyol edebiyatı, polisiye roman, ekofeminizm, Baztán Üçlemesi

\section{Nature and myth in detective novel: The Baztán Trilogy}

\begin{abstract}
Detective novel in Spanish literature arises from the pen of the male writers as in other countries' literatures and continues to develop from a male gaze. In the middle of the XXth century it gains proper recognition in the literary world. In the 1970 s it first appears with a political identity. After the death of Franco in 1975 female writers also begin to write detective novels. In the 1980 s with the feminist movement's gaining momentum in Spain, the sexist structure of detective novel begins to be broken with female detectives created by the female writers. This study examines the breaking points of the ongoing sexist structure of the detective novel genre through the Baztán Trilogy written by Dolores Redondo between 2013-2014. The construction of the Baztán Trilogy, composed of The Invisible Guardian (2013), The Legacy of the Bones (2013) and Offering to the Storm
\end{abstract}

Bu makale, İstanbul Üniversitesi, Sosyal Bilimler Enstitüsü, Batı Dilleri ve Edebiyatları Ana Bilim Dalı, İspanyol Dili ve Edebiyatı Bilim Dalı bünyesinde tamamlanan “Çağdaş İspanyol Polisiye Romanında Kadın Kimliğinin Oluşumu” başlıklı Doktora tezinden üretilmiștir.

2 Dr. Arş. Gör., Burdur Mehmet Akif Ersoy Üniversitesi, Fen Edebiyat Fakültesi, Batı Dilleri ve Edebiyatları Bölümü, İspanyol Dili ve Edebiyatı ABD (Burdur, Türkiye), zduran@mehmetakif.edu.tr, ORCID ID: oooo-0003-1996-7214 [Araștırma makalesi, Makale kayıt tarihi: 29.04.2021-kabul tarihi: 20.06.2021; DOI: 10.2900o/rumelide.949942]

Adres Address

RumeliDE Dil ve Edebiyat Araşttrmaları Dergisi $\quad$ RumeliDE Journal of Language and Literature Studies Osmanağa Mahallesi, Mürver CCiçeği Sokak, No:14/8 Osmanağa Mahallesi, Mürver Çiçeği Sokak, No:14/8

Kadıköy - İSTANBUL / TÜRKIYE 34714 Kadıköy - ISTANBUL / TURKEY 34714 e-posta: editor@rumelide.com

e-mail: editor@rumelide.com,

tel: +90 $5057958124,+90216773$ o 616 phone: +90 505 7958124, +90 216773 o 616 
(2014), is nurtured by Basque mythological figures. The protagonist of the trilogy, female detective Amaia Salazar, is identified with the female goddess Mari/Maya of the Basque mythology. In addition to this identification some allegories such as forest, river and cave which point to return to the mother's womb are repeated throughout the narrative. The components of dualities that form the basis of the Western thought undergo a questioning through cultural ecofeminist approach. Affirming the connection established between woman and nature, the affinity of woman with nature is glorified through motherhood. By pointing to matriarchy, metaphor of mother earth is animated and female identity is redefined. Thus, the ongoing sexist structure of the detective novel in Spanish literature is subverted through the fictional female detective and the genre undergoes a rewriting.

Keywords: Spanish literature, detective novel, ecofeminism, the Baztán Trilogy

\section{Giriş}

Dedektiflik figürünün ilk arketipi olarak XIX. yüzyılın son çeyreğinde ortaya çıkan Sherlock Holmes, sıradan insan zayıflıklarından ve tutkularından uzak bir adamdır. Birçok bilim dalında yetkin olan, asla hata yapmayan, olayları saf analitik mantıkla çözen ve akılla özdeşleşen Sherlock Holmes, kusursuzluk örneği olarak sivrilir. Sherlock Holmes romanlarıyla rasyonalite ve üst orta sinıf erkeklik yüceltilir ve yayılır (Munt, 1994: 2).3 XX. yüzyılın ilk yarısında polisiye romanın altın çağının yaşandığı dönemde Amerika'da ortaya çıkan hard-boiled polisiye roman alt türüyle birlikte Sherlock Holmes romanlarında yüceltilen erkek, bu sefer tanrlaş̧tırlır ve her şey haline gelir. Şiddetin, vahşetin ve zulmün bolca görüldüğü hard-boiled romanlarda kurgulanan dedektifler tehlikeye açı, cesur, bağımsız, zeki, içki ve sigara içen, genellikle yalnız erkeklerdir. Erkeğin akılla özdeşleştirilerek üstün tutulduğu bu romanlarda kadın cinsi önce karanlık, bölücü ve anlaşılmaz, daha sonra da erkek egemenliğini tehlikeye sokan taraf olarak varlık gösterir. Yoğun bir erkeksiliğin hâkim olduğu hardboiled türündeki romanlarda kadın, her zaman kontrol altında tutulması gereken tehlikeli ötekidir (Reddy, 2003: 194). Bu romanlarda kadın, kurban, bir erkeğin yardımcısı, sekreter veya femme fatale olarak stereotipleşir. Dolayısıyla erkek yazarların kaleminden doğan ve hegemonyaları altında gelişen polisiye roman, cinsiyete dayalı bir yapıdadır; bu romanlarda toplumsal cinsiyet kimlikleri önceden belirlenmiş olup, "dedektif” biyolojik cinsiyetinden bağımsız bir şekilde sembolik olarak erkek pozisyonunu, "kurban" yani kadın, bedene indirgendiğinden dolayı dişil pozisyonu temsil etmektedir (Bedore, 2008: 21). Erkeğin akılla, kadının ölümle özdeşleştirildiği bu roman türüyle mevcut toplumsal cinsiyet kimlikleri yeniden kurularak sağlamlaştırılır ve sürdürülür.

1960'larda ikinci dalga feminist hareketin edebi alanda etkisini göstermesiyle birlikte kadın yazarlar romanlarında erkek dedektife denk kadın dedektif figürleri yaratmaya başlarlar ve mizojinist bir yapıyla doğup gelişen polisiye roman türünün dayandığı cinsiyet politikalarını sorgulamaya açarlar. 1960'larda yazmaya başlayan kadın yazarlar öncelikle XX. yüzyılın başında kurgulanmış, mevcut toplumsal cinsiyet kimliklerinin sürdürülmesine katkı sağlayan kadın dedektif stereotiplerine karşı eleştirel bir tutum benimserler. Erkek dedektife denk düşecek şekilde kurguladıkları sigara ve içki içen, cesur, bağımsız, zeki ve başarılı kadın dedektif figürleriyle XX. yüzyılın ilk yarısında Agatha Christie’nin yarattığı Miss Jane Marple karakteriyle stereotipleşen evde kalmış, yaşlı kız kurusu kadın dedektif figürünü geride bırakırlar. 1980'li yıllara gelindiğinde feminist polisiye roman altın çağını yaşar (Munt, 1994: 196). Bu dönemden itibaren kadın polisiye roman yazarları, polisiye romanın erkek egemen yapı olarak en dirençli olduğu hard-boiled alt türüne toplumsal cinsiyet farkındalı̆̆ını sokma

Bu makalede kullanılan çeviri eserler dışında İngilizceden ve İspanyolcadan Türkçeye yapılan bütün çeviriler tarafıma aittir.

RumeliDE Dil ve Edebiyat Araștırmaları Dergisi Osmanağa Mahallesi, Mürver Ciçeği Sokak, No:14/8 Kadıköy - ISTANBUL / TÜRKIYE 34714 e-posta: editor@rumelide.com tel: +90 $5057958124,+902167730616$
Address

RumeliDE Journal of Language and Literature Studies

Osmanağa Mahallesi, Mürver Çiçeği Sokak, No:14/8

Kadıköy - ISTANBUL / TURKEY 34714

e-mail: editor@rumelide.com,

phone: +90 5057958124 , +90 2167730616 
girişiminde bulunurlar. Carolyn Gold Heilbrun, yaratılan bu kadın dedektiflerin Amerikalıların bağımsız, tek başına hareket eden, adalet ve kanun yerine sadece işiyle ilgilenen maço özel dedektif figürüyle İngilizlerin daha naif, yasalara bağlı ve genellikle amatör olan dedektif figürünün birleşiminden oluşturulduğunu ileri sürer (2002: 420). Feminist öğretiler paralelinde kurgulanan, pasifliği bırakıp harekete geçen bu kadın dedektifler erkekleri hayatlarının ilk sırasına koymazlar. Evlilik fikriyle baştan çıkmazlar. Evliliği, bağımsızlıklarını engelleyici bir unsur olarak görürler. Genelde ailelerinden kopmuş, çocuksuz olan bu kadınlar, etraflarındaki genç kadın veya kız çocuklarına akıl hocalığı yaparlar. Polisiye roman aracılığıyla sağlamlaştırılan ve sürdürülen erkek egemen otoriteye bir karşı duruş olarak erkeklere benzer şekilde argo bir dil kullanırlar, gerekli hallerde silah veya fiziksel güç kullanırlar ve cinsel hayatlarını özgür bir şekilde yaşarlar. Soruşturma sırasında tehlikeye atılmaktan çekinmeyen, silah kullanan, kendine yeten bu kadın dedektiflerin yer aldığı polisiye romanlarda ele alınan konular kadın zulmüyle ilişkilendirilir. Romanlarda anlatının merkezinde taciz, tecavüz, kürtaj, çocuk istismarı veya aile içi şiddet gibi feminizmin üzerinde durduğu konular yer alır. Dolayısıyla çağdaş dönemde kadın yazarlar tarafından kurgulanan feminist polisiye romanlarla birlikte türün erkek egemen anlatı aşkınlığı reddedilir. Kurgulanan kadın ve erkek dedektif kimlikleriyle toplumsal cinsiyet kimliklerinin yapaylı̆̆ına işaret edilir. Androjenlik kavramına vurgu yapılarak ataerkil sistemin temel dayanağı olan ikilikler ağının kurgusallığı ve değiştirilebilir olduğuna dikkat çekilir. Çağdaş dönemde yazan ve türün cinsiyetçi yapısını kıran yazarlardan biri İspanyol yazar Dolores Redondo'dur. Bu çalışmada Redondo'nun 2013-2014 yılları arasında yazdığı ve ekofeminist bir yaklaşım sergilediği düşünülen Baztán Üçlemesỉni incelemek ve elde edilen veriler üzerinden polisiye roman türünün cinsiyetçi yapısının kırılma noktalarını tespit etmek hedeflenmiştir.

\title{
Ekofeminizme kısa bir bakış
}

Terim olarak ekofeminizmi ilk olarak 1974 yllında feminist aktivist Françoise d'Eaubonne, Le Féminisme ou la Mort adlı kitabında kullanır. Ekofeminizm, kadınların egemenlik altına alınmalarıyla doğanın egemenlik altına alınmasının bir bütün oluşturduğu ilkesine dayanır (Donovan, 2016: 399). Buna göre kadınlara yönelik baskı ile doğaya yönelik baskı arasında bir bağlantının olduğu ve bu ikisinin özgürlüğünün birbirine bağlı olduğu düşünülür. Her ikisinin de baş düşmanı ataerkil sistemdir; çünkü ataerkil sistem, temelindeki hiyerarşik ikilikler ağıyla erkeği ve kültürü merkeze koyarken kadını ve doğayı ikincil ve edilgen olarak konumlandırır. Dolayısıyla feminizmi ve ekolojik yaklaşımı bir araya getiren ekofeminizmde temel amaç "tarihi süreçte kadınlar ve doğa arasında kurulan bağlantıları ortaya koymak ve ortaya koyulan bu bağlantıların eleştirisiyle ataerkil tahakkümü zayıflatmak" olarak ortaya çıkar (Özdemir\&Aydemir, 2019: 269). Val Plumwood bu durumu şu şekilde ifade eder:

\begin{abstract}
“Tüm ekolojik feminist konumların temel bir özelliği, Batı'da olumsuz bir kültürel değer yüklenen ve kadınların değersizleştirilip ezilmesinin başlıca temelini oluşturan kadın-doğa bağlantısına olumlu bir değer yüklemesidir. Ekolojik feministler kadınların, kadınlığın ve doğanın statüsünü kültürel açıdan yeniden değerlendirmeye çalışırlar; bu yeniden değerlendirme, Batı kültüründe bunlar arasındaki tarihsel bağlantının hem kadın kimliğinin hem de erkek ve insan kimliğinin inşasını nasıl etkilediğini dikkate almak zorundadır.” (2020: 20)
\end{abstract}

Plumwood, Batı'daki bu ikilikler ağının, dişilliği doğaya bağlayıp edilgin hale getirmesinin yanı sıra genelde erkeklerden ve beyazlardan oluşan bir seçkinler grubunun doğa alanını dışlayıp tahakküm altına almalarıyla bir efendi modeli oluşturduklarını ileri sürer ve ekler: "İşte bu yüzden kadınları doğaya bağlayan eski geleneği reddetmekle yetinmeyip, yerine hiçbir şey koymamak çoğunlukla alternatif bir efendi modelini ve insanın doğayla ilişkilerini sessizce onaylayıp kadını da bu modelde eritmek demektir" (2020: 40). Dolayısıyla birbiriyle sıkı bir bağlantı içinde olduğu anlaşılan doğa ve

Adres | Address

RumeliDE Dil ve Edebiyat Araşttrmaları Dergisi $\quad$ RumeliDE Journal of Language and Literature Studies Osmanağa Mahallesi, Mürver Çiçeği Sokak, No:14/8 Osmanağa Mahallesi, Mürver Çiçeği Sokak, No:14/8

Kadıköy - İSTANBUL / TÜRKIYE 34714 Kadıköy - ISTANBUL / TURKEY 34714 e-posta: editor@rumelide.com tel: +90 505 7958124, +90 2167730616 phone: +90 505 7958124, +90 2167730616 
kadının erkek egemenliğinden kurtulması için mevcut ikilikler ağının incelenip yeniden değerlendirilmesi zorunlu hale gelir.

Ekofeministler, Karen Warren'ın ifade ettiği üzere kadın ve doğanın tahakkümü arasında bir ilişki olduğu; bu tahakkümü anlamak için ilişkinin özünü anlamak gerektiği; feminist eylemin ekolojik, ekolojik sorunlara getirilen çözümlerin de feminist bakış açısına sahip olması gerektiği noktalarında birleşirler (aktaran Demir, 2013: 16). Fakat kadının tahakküm altına alınışı ve doğanın tahribi arasındaki ilişkinin özü noktasında farklı düşünceler ileri sürerler. Buna göre bazı ekofeministler kadın ve erkek arasındaki farka vurgu yaparak ekoloji ve kadın arasında bir ilişki kurarlar. Kültürel ekofeminizm olarak da bilinen bu yaklaşıma göre kadın ve erkek, doğa ve kültür, öz itibariyle birbirinden farklıdır; buna göre kadın doğayla, erkek ise kültür ve medeniyetle ilişkilidir. Kadın, biyolojisi itibariyle doğaya benzemektedir; doğa gibi besleyici, koruyucu ve hayat vericidir. Buradan hareketle "bugün, doğa anaya karşı saldırıya geçen ve kadınların da baskı altında tutulmasını destekleyen modern kültüre karşı, öz itibariyle doğaya yakın olan kadınlar mücadele etmeli; kültürün erkek egemen değerlerine karşı kadınsı değerlerle karşı çıkılmalıdır” (Demir, 2013: 19) düşüncesi öne çlkar. Konuyla ilgili söylemlerinde özcü bir yaklaşım taşıyan Mary Daly, erkek kültürünü reddederek kadın kültürünü benimser ve ataerkil dönem öncesinde var olan anaerkil dönemi işaret ederek kadınların özgürleşmelerinin onların bu eski dünya ile yeniden temasa geçmeleriyle sağlanacağını ileri sürer (aktaran Tong, 2006: 430). Benzer şekilde Susan Griffin de kadın ve doğa arasındaki derin bağdan bahseder ve şöyle der:

"Kendimizin bu dünyadan yapıldığını biliyoruz. Bu dünyanın da bizim bedenlerimizden yapıldığını biliyoruz. Çünkü kendimizi görüyoruz. Ve bizler doğayız. Bizler doğayı gören doğalarız. Doğa kavramına sahip doğalarız.” (1978: 226).

Kültürel ekofeminist görüşte kadın doğayla özdeştir. Bu nedenle bu anlayışta tarih öncesi dönem önem kazanır. "Kültürel ekofeminizmin toplumsal ekolojik anlayıştaki hedefi, eril alana dahil edilen rasyonalite kategorilerini dışlayarak, ana tanrıça inançları, mitler ve ruhsallığı ön plana çıkartmaktır" (Yılmaz Aslantürk, 2018: 318). Buna göre Pelin Kümbet'in de belirttiği gibi birçok ekofeminist modern çă̆ öncesine ait Gaia ve Doğa Ana kavramlarından ilham almış ve bu imgeleri yeniden canlandırmaya çalışmışlardır (2012: 181). Bu makalede inceleme nesnesi olan Baztán Üçlemesi’nde de tarih öncesi dönem ön plana çıkar. Üçlemenin kahramanı kadın dedektif ile Bask mitolojisindeki dişi tanrıça Mari/Maya arasında bir özdeşleşim kurulur. Kurulan bu özdeşleşimle kadın/doğa benzeşimi onaylanır. Annelik kavramı üzerinden kadın/doğa benzeşimi vurgulanır ve yüceltilir. Dolayısıyla üçleme, kültürel ekofeminist bir yaklaşım sergileyerek polisiye roman türünün cinsiyetçi yapısını kırar ve tür içinde bir yeniden yazıma olanak tanır.

\section{Baztán Üçlemesi’nin incelenmesi}

Dolores Redondo'nun satanizmin gölgesinde işlenen gerçek bir bebek cinayetinden 4 esinlenerek 20132014 yılları arasında yazdığı Baztán Üçlemesi ${ }^{5}$, polisiye romanın police procedural ${ }^{6}$ alt türündedir.

$4 \quad$ Dolores Redondo, üçlemeyi 2011 yllında çıkan bir haber üzerine kurgular. Habere göre on dört aylık Ainara isimli bir kız bebek, tarikata üye olan anne babası tarafından kurban edilerek öldürülmüştür. Cinayet otuz yıl boyunca gizli kalmış, otuz yılın ardından gelen bir ihbar üzerine ortaya çıkmıştır. İhbarı yapan kişi, Ainara’nın kurban edildikten sonra Lesaka yakınlarında tarikat üyelerinin kaldığı büyük bir konağın yakınlarına gömüldüğü bilgisini vermiştir. Haberin detayları için bakınız:

https://www.abc.es/deportes/abcp-guardia-civil-investiga-asesinato20111030000o_noticia.html?ref=https:\%2F\%2Fwww.google.com\%2F

5 Kısa bir sürede büyük bir kitle tarafından okunan ve birçok farklı dile çevrilen Baztán Üçlemesi sinemaya da uyarlanmıştır. Üçlemenin birinci romanı 2017 ylında, ikinci romanı 2019 yılında, üçüncü romanı ise 2020 yllında gösterime girmiştir.

RumeliDE Dil ve Edebiyat Araștırmaları Dergisi Osmanağa Mahallesi, Mürver Ciceği Sokak, No:14/8 Kadıköy - ISTANBUL / TÜRKIYE 34714 e-posta: editor@rumelide.com tel: +90 $5057958124,+902167730616$
Address

RumeliDE Journal of Language and Literature Studies

Osmanağa Mahallesi, Mürver Çiçeği Sokak, No:14/8

Kadıköy - ISTANBUL / TURKEY 34714

e-mail: editor@rumelide.com,

phone: +90 5057958124, +90 2167730616 
Üçlemenin kahramanı Amaia Salazar, Navarra Özerk Polis Teşkilatı'nda polis dedektifidir. James adında Amerikalı bir heykeltıraşla evli olan ve Pamplona'da yaşayan Amaia, Quantico'da FBI'ın ajan okulunda eğitim almış başarılı bir polistir. Baztán vadisinde küȩük bir kasaba olan Elizondo'da doğar fakat yaşadı̆̆ travmatik çocukluktan sonra oradan uzaklaşır. Amaia'nın anne ve babası, 1865 yılında kurulan Navarra'nın en eski firınlarından olan Mantecadas Salazar’ı işletirler. Babası öldükten, annesinin de çalışamaz duruma gelmesinin ardından işletmenin başına Amaia'nın büyük ablası Flora geçer. Vīctor ile evli olan Flora, dominant, sert ve sivri dilli bir kadındır. Freddy ile evli, uyumlu ve daha ılımı ıir kadın olan Amaia’nın diğer ablası Rosaura ise Flora'nın yanında aile fırınlarında çalışır.

Otuzlu yaşlarındaki genç polis dedektifi Amaia Salazar annesi tarafından hiç sevilmez. Anne sevgisinden mahrum kalarak büyümesinin yanı sıra annesi tarafından öldürülmeye çalışılır. Annesiyle olan travmatik ilişkisinden dolayı TSSB yani travma sonrası stres bozukluğuyla mücadele eder. Dokuz yaşında annesi tarafından uğradığı öldürülme girişiminden sonra babası, Amaia’yı doktor tavsiyesiyle evden uzaklaştırır ve kardeşi Engrasi'nin yanına gönderir. O günden sonra halasıyla yaşayan Amaia, sadece hafta sonları kendi ailesinin yanına gider ve onlarla birlikte geçirdiği birkaç saatin ardından korku içinde tekrar halasının evine döner. Çocukken annesinin tam uyumak üzereyken üzerine eğilip onu öldüreceğini fısıldamasının yarattığı travmadan dolayı karanlıkta uyumaktan korkar, kâbuslar görür ve yalnız uyumamak için bazen saatlerce uyanık bekler. FBI tecrübesi ve Elizondolu olması nedeniyle Elizondo'da işlenen seri cinayet soruşturmasının başına getirilince köklerine, çocukluğuna ve travmalarına geri dönmek, onlarla yüzleşmek zorunda kalır.

Üçlemede işlenen cinayetler kahramanın kendi içine yapacağı bir yolculuğu zorunlu kılar. Üçlemenin birinci romanı El Guardián Invisible'de (Görünmez Muhafiz) cinayetlerin, doğduğu yerde işlenmesinden dolayı soruşturmanın başına getirilen Amaia, üçlemenin ikinci romanı Legado en los Huesos (Kemiklerin Mirası) ve üçlemenin son romanı Ofrenda a la Tormenta'da (Firtınaya Adak) birbirine bağlı şekilde işlenen ve kahramanı da içine alan seri cinayetlerin devam etmesiyle soruşturmanın başında kalmaya ve kendi içine yolculuk yapmaya devam eder. El Guardián Invisible'de Baztán nehrinin kenarına atılan ergenliğe yeni girmiş genç kız cesetlerinin faili Amaia'nın büyük ablası Flora'nın kocası Vīctor'dur. Legado en los Huesos'da kilisedeki kutsal eşyalara karşı bir saldırı düzenlenir. Paganlara ait olduğu düşünülen bir ayin sonrası bırakılan mairu-beso7 (kutsal emanet), yapılan DNA incelemesi sonucunda Amaia'nın atalarının kemiklerine ait çlkar. Kilisede düzenlenen ikinci saldırıda bırakılan kemikler ise Amaia'nın varlığından bu olay sayesinde haberdar olduğu ikizine ait kemiklerdir. Romanın sonunda bu eylemlerden sorumlu olan kişilerden birinin kimliği ortaya çıkar fakat bu kişinin Amaia'nın annesini yattığı hastaneden kaçırmasıyla soruşturma tamamlanamaz. Ofrenda a la Tormenta'da bölgede gerçekleşen ani bebek ölümleri soruşturmaya dâhil olur ve diğer cinayetlerle bağlantılı oldukları anlaşılır. Anlatının sonunda bütün cinayetlerin Amaia'nın annesinin de üyesi olduğu bir tarikattan kaynaklandığı ortaya çıkar. Amaia'nın annesi intihar ederek ölür. Dolayısıyla üçleme boyunca suçun araştırılma hikâyesi, polis dedektifinin geçmişi

Police procedural alt türünde soruşturmayı yürüten kişi Polis Teşkilatı'na bağlıdır ve belirli kurallar çerçevesinde olayları çözer. Leroy L. Panek, polislerin 1950’lerden önce polisiye romanlarda daha çok yan karakterler olarak kurgulandıklarını fakat 1950'lerden sonra yavas yavas bu durumun değismeye başladığını ifade eder. İkinci Dünya Savaşı ve Vietnam Savaşı'ndan sonra Amerikan toplumunda yaşanan sosyopolitik ve sosyokültürel değişimlerin polisiye roman yazarlarının romanlarında gerçek polislere ihtiyaç duymalarına sebep olduğunu ve police procedural alt türünün bu şekilde ortaya çıktığını ileri sürer. Aynı şekilde police procedural polisiye roman alt türünün, Lawrence Treat'ın 1945 ylında yayımlanan V As in Victim romanıyla Joseph Wambaugh'un 1973 yllında yayımlanan The Chairboys romanı arasındaki süreçte yavaş bir şekilde gelişim gösterdiğini; 1980'lerden sonra tam anlamıyla yayıldığını belirtir (Panek, 2003: 155-156).

$7 \quad$ Mairu-beso Baskça bir terimdir ve Bask kültürüyle alakalıdır. Mairu, vaftiz edilmeden ölen ve evin yakınlarına gömülen bebeklere verilen isimdir. Mairu-beso, vaftiz edilmeden ölen bu bebeğin kolu anlamına gelmektedir. Bask geleneğinde vaftiz edilmeden ölen bu bebekler evin yakınlarında itxusuria adı verilen bir yere gömülürler. İnanışa göre bu bebeklerin ruhları, ev halkını korumaktadır.

RumeliDE Dil ve Edebiyat Araşttrmaları Dergisi Osmanağa Mahallesi, Mürver Cicceği Sokak, No:14/8 Kadıköy - İSTANBUL / TÜRKIYE 34714 e-posta: editor@rumelide.com tel: +90 $5057958124,+90216773$ o 616
Address

RumeliDE Journal of Language and Literature Studies Osmanağa Mahallesi, Mürver Çiçeği Sokak, No:14/8

Kadıköy - ISTANBUL / TURKEY 34714

e-mail: editor@rumelide.com,

phone: +90 5057958124 , +90 216773 o 616 
hakkındaki sır perdelerini kaldırmasına, kendisi ve ailesi hakkında bilmediklerini öğrenmesinin hikâyesine dönüşür.

Baztán Üçlemesỉnde Bask bölgesinin kültürel yapısını oluşturan Hristiyanlık öncesi dönemde var olmuş pagan inançlar ve ağızdan ağıza aktarılan efsaneler ön plana çıkar. Kurgu, Bask bölgesinin coğrafyası, gelenekleri, inançları, kısacası Bask folklorik unsurlarıyla şekillenir. Bask bölgesi anaerkil bir geleneğe sahiptir. Dolores Redondo, bir dergi röportajında anaerkil bir topluma ait olmanın tarih boyunca Bask kadınlarının güçlü, cesur ve erkeklerle saygı çerçevesinde eşit bir şekilde yaşamalarına olanak sağladığını belirtir. Dünyaca ünlü İspanyol antropolog, etnograf ve tarihçi Julio Caro Baroja, En Los Pueblos del Norte'de Estrabon, Justino ve Trogo Pompeyo gibi isimlerin klasik metinlerine dayanarak bölgede anasoylu bir toplum geleneğinin varlığından bahseder. Aynı şekilde Basklı antropolog, etnograf ve rahip José Miguel de Barandiaran, ardından filozof Andrés Ortiz de Osés, dişi tanrıça Mari'nin etrafında şekillenen Bask mitolojisindeki dişi tanrıçaların öneminden yola çıkarak anaerkil bir Bask kültürünün varlığından söz eder (aktaran Valle Murga, 1982: 125). Bu bağlamda üçlemede uzamsal olarak anasoylu bir gelenekle öne çlkan Bask bölgesinin kullanılması, kültürel ekofeminist yaklaşımın kurtuluşu anaerkil dönemde araması düşüncesiyle örtüşür.

Anaerkillik, üçlemede kurgulanan aile yapılarıyla da vurgulanır. Tarih boyunca kadın kimliği annelik ve evlilik üzerinden tanımlanır. İkinci dalga feminizmde evlilik ve aile kavramı ataerkinin temel dayanakları olarak görüldüğü için eleştirilir. Evliliğin ve ailenin, kadını kamusal alandan uzaklaştırıp domestik alana hapsettiği düşünülür. Çağdaş dönem İspanyol edebiyatında kadın yazarlı polisiye romanlarda bu düşünce etkisini sürdürür. Özellikle Franco'nun ölümünden sonra 1980'li yıllarda kadın yazarlı polisiye romanlarda kurgulanan kadın dedektif, bağımsızlı̆̆ını riske edecek her şeyden olduğu gibi evlilik ve aile kavramlarından da uzak durur. 1990'lı ve 200o'li yıllarda değişen düşünce ve toplum yapısıyla birlikte bu romanlarda evlilik ve aile, dedektifin şüpheyle yaklaştığı fakat kimliğiyle bütünleştiremediği kavramlara dönüşür. Fakat XXI. yüzyılda yazılan feminist polisiye romanlarda kadın dedektif, artık eskisi gibi yalnız değildir. Romanlarda herhangi bir topluluğa ait bir birey olarak varlık gösterir. Baztán Üçlemesìnde bu topluluk ailedir. Üçlemede Amaia Salazar'ın hem kendi ailesi hem de eşiyle kurduğu aile anlatının merkezindedir. Dedektifin içinde bulunduğu bu aile yapıları ataerkilliğin uzantısı olmaktan uzaktır. Her iki aile de anaerkildir. Bu ailelerde kadınlar baskındır, güçlüdür ve başarılıdır. Bunun karşısında erkekler ya psikolojik olarak hadım edilmişlerdir ya da Amaia'nın kocası James gibi yeni maskülen8 bir yapıya sahiptirler. Aile yapılarının anaerkil oluşu, anlatıda uzamsal olarak kullanılan Bask bölgesinin anaerkil geleneğiyle de örtüşmektedir. ${ }^{9}$

Amaia, James ile olan evliliğinde geleneksel ataerkil aile modelinden uzaktır. Kadın dedektif, evlilikle birlikte mesleğini bırakıp domestik alana hapsolmaz, bağımsızlı̆̆ını riske atmış olmaz. Bilakis, James'in yeni maskülen yapısı, her koşulda Amaia'yı desteklemesi ve yanında olması evlilik ve aile kavramlarını geleneksel polisiye romandakinin aksine kadın dedektifin kimliğini tamamlayan önemli unsurlara dönüştürür. Amaia'nın kendi ailesinde de kadınlar güçlü kişiliklere sahiptir. Amaia’nın

$8 \quad$ Yeni maskülen erkek figürü (nueva masculinidad), çağdaş dönemde değişen toplum yapısıyla birlikte ortaya çlkan yeni bir erkek kimliğidir. Yeni maskülen erkek, dominant ve otoriter erkek figüründen oldukça uzaktır. Bu erkek figürü sevgisini, samimiyetini ve doğallı̆̆ını daha iyi ifade edebilen erkektir. Ebeveyn olarak despotluktan ve ataerkil/sert babalıktan uzaktır. Temel hedefleri cinsiyet farkı gözetmeksizin çocuklarına nasıl daha iyi insanlar olabileceklerini öğretmektir. Böylece duygusal maçoluğu yeniden üreten geleneksel erkeklik modelinde olan baba figürü ortadan kalkmış olacak ve gelecek kuşaklar bu yeni maskülen erkek figürünün ne anlama geldiğine dair gerçek ve yakın referanslarla şekilleneceklerdir (Checa Salazar\&Cid del Prado Rendón, 2003: 39).

9 Üçlemenin yazarı Dolores Redondo röportajlarında kendi aile yapısının da anaerkil oluşunu dile getirir. Denizci olan babasının ve çevresindeki diğer erkeklerin evden uzun süreli uzak kalmak zorunda oluşlarından dolayı Bask kadınlarının çocukların bakımıyla, bahçeyle ve hayvanlarıyla tek başlarına uğraştıklarından bahseder (Sainz Borgo, 2019; Arenas, 2015).

Adres

RumeliDE Dil ve Edebiyat Araşttrmaları Dergisi Osmanağa Mahallesi, Mürver Ciceği Sokak, No:14/8 Kadıköy - İSTANBUL / TÜRKIYE 34714 e-posta: editor@rumelide.com tel: +90 $5057958124,+90216773$ o 616
Address

RumeliDE Journal of Language and Literature Studies Osmanağa Mahallesi, Mürver Çiçeği Sokak, No:14/8

Kadıköy - ISTANBUL / TURKEY 34714

e-mail: editor@rumelide.com,

phone: +90 5057958124 , +90 216773 o 616 
babası anlatı boyunca sadece geçmişe giden zaman sıçrayışlarında var olur ve erken yaşta ölerek aile içinde silik bir figür olarak yer alır. Amaia'nın annesi Rosario'nun eşi üzerinde hadım edici bir etkisi vardır. Rosario, Amaia ve ikizine hamileyken tuhaf davranışlar sergiler. Geceleri tek başına evden çıkıp ayinlere katılır ve sabaha karşı eve döner. Kocası merak edip nerede olduğunu sorduğunda ise doğru düzgün cevap vermeyi reddederek onu tersler. Hamileliğinden dolayı böyle olduğunu düşünüp ona bir yardımcı almayı teklif ettiğinde ise çlgına döner ve kocasını, evi terk etmekle tehdit eder. Juan, Rosario'dan bir çocuk gibi korkar: "Gizliden gizliye korkuyordu; baskın bir anne karşısındaki korkak bir erkek çocuğu gibi” (Redondo, 2016: 61). Anlatı boyunca dedektifin üzerindeki etkisi sürekli hissedilen annesi Rosario'nun aksine babası Juan'ın adı sadece bir kere geçer ve anlatıda hayalet bir figür olarak kalır. Kocası üzerinde ezici bir güce sahip olan Rosario ise üçlemenin sonuna kadar kadın dedektifin hem gerçek anlamda hem de sembolik anlamda mücadele ettiği büyük bir güce dönüşür.

Amaia'nın büyük ablası Flora da kendi ailesi içinde güçlü ve baskın bir karakterdir. Kocası Vìctor üzerinde hadım edici bir etki10 yaratır. Bu haliyle Flora, Judith Fetterley'in ileri sürdüğü castrating bitch (hadım edici kadın) figürüne dönüşür. Fetterley, hadım edici kadın stereotipinin çok karşılaşılan edebi stereotiplerden biri olmasına rağmen kültürel gerçekliğin aslında kadınların erkekleri dişileştirmesi değil, erkeklerin kadınları erilleştirmesi olduğunu belirtir (1978: xx). Fetterley'in ifade ettiği gibi kadınlar, ataerkil toplum içinde erkekler gibi düşünmeye ve erkek bakış açısıyla özdeşleşmeye yönlendirilirler. Bu kadınlar, kadın nefretini de içinde barındıran erkek egemen sistemi ve değerleri olduğu gibi kabul ederler. Hadım edici kadın stereotipindeki Flora da kocası Vīctor’u psikolojik olarak hadım eder ve onun seri katile dönüşmesinin sebeplerinden biri olur. Seri katil Vìctor, romanda gelenekselliği temsil eder. Vīctor'un cinayetleri işlemesinin sebebi, Flora'yı memnun etmek istemesi ve gelenekselliğe olan takıntısıdır. Öldürdüğü genç kızlar üzerinde uyguladığı ritüeller de geleneksellik takıntısına gönderme yapar. Öldürdüğü genç kızların kadınsı kıyafetlerini çıkarır, genital bölgelerindeki kılları tıraş eder, avuçlarını gökyüzüne açık bir şekilde konumlandırır. Kasıklarına bölgenin geleneksel tatlısı olan txantxigorri koyar ve cesetleri Baztán vadisinde nehir kenarına bırakır. Bu ritüellerle kadın olma yolunda ilerleyen genç kızları bir daha hiç büyümemek üzere çocukluklarına geri gönderir. Vīctor, bu genç kızların süslenmelerinden, erkeklerle olan ilişkilerinden ve kadınsı davranışlarından rahatsız olur ve onları öldürür. Bu tutumuyla Batı düşünce sisteminin ikilikler ağındaki kültür/doğa ikiliğinden kültürle özdeşleşen ve doğanın dengesini bozan Vīctor, ataerkil toplumdaki kadın düşmanlığını temsil eder. Bu düşünce yapısını Judith Fetterley’in söylemine denk düşecek şekilde hadım edici eril kadın figüründeki Flora da benimser. Ailece yemek yedikleri sırada cinayetlerden konu açılınca Flora, öldürülen genç kızları suçlayıcı şekilde konuşur. Genç kızların davranışlarından dolayı ölümü hak ettiklerini ifade eder:

"Bu kızlar o tiplerden diyorum; giyimlerinden, konuşmalarından ve davranışlarından bıktım. Ortalık malı gibiler; erkeklerle olan davranışları utanç verici. Size yemin ederim ara sıra meydandan geçerken onları görüyorum, yollu kadınlar gibi vücutlarının yarısı erkeklerin üzerinde; sonlarının böyle olmasına şaşırmıyorum.” (Redondo, 2017: 365)

Flora, söylemiyle erkek bakış açısını benimser, ataerkil sistemin kadınlar için uygun gördüğü ve belirlediği kuralların savunuculuğunu yapar. Ataerkinin kadın düşmanlığını benimser ve başka kadınların ölümüne sebep olur. Fakat diğer yandan Flora'nın gücünü Vīctor’a karşı, yani gelenekselliğin/ataerkinin kendisine karşı da kullanmış oluşuyla ataerkil sistemin altı oyulur. Sistemin kendisi yüzünden ortaya çıkan bu kadın figürü yine sistemin baltalayıcı figürlerinden birine dönüşür.

Burada hadım etmek, penisi kesmek anlamında değil; psikolojik olarak karşıdaki kişinin yaşam enerjisini emmek, tüketmek anlamında kullanılmıştır.

RumeliDE Dil ve Edebiyat Araștırmaları Dergisi Osmanağa Mahallesi, Mürver Ciçeği Sokak, No:14/8 Kadıköy - İSTANBUL / TÜRKIYE 34714 e-posta: editor@rumelide.com tel: +90 $5057958124,+902167730616$
Address

RumeliDE Journal of Language and Literature Studies

Osmană̆a Mahallesi, Mürver Çiçeği Sokak, No:14/8

Kadıköy - ISTANBUL / TURKEY 34714

e-mail: editor@rumelide.com,

phone: +90 5057958124 , +90 2167730616 
Flora, kocası Vīctor'un üzerindeki ezici gücünden başka Amaia'nın ekibinden polis dedektifi Montes’i de etkisi altına alarak soruşturma sürecinde onu manipüle eder. Dişiliğini kullanarak Montes’i baştan çıkarıp soruşturmanın seyri hakkında bilgi alır ve katil kocası Vīctor'un polisler tarafından yakalanmasını engeller. Fakat anlatının sonunda Vīctor'u Flora'nın kendisi öldürür. Kocasının katil olduğunu bilmesine rağmen ylllarca susup sonunda öldürmesinin sebebi Vīctor'un kurbanlarından biri olan Anne Arbizu'nun Flora'nın herkesten gizlediği kendi kızı olmasıdır. Bu haliyle Flora, erkek yazarlı polisiye romanlardaki femme fatale kadın stereotipini temsil eder. Fakat erkek yazarlı polisiye romanlarda süregeldiği gibi cezalandırılıp ölmez; çünkü üçlemede, femme fatale, erkeği baştan çıkaran tehlikeli öteki olmaktan daha çok ataerkinin kendi eliyle yarattığı bir canavar olarak yansitılır. Böylece ataerkil sistem eleştirilir ve ataerkinin kendi kendini tüketmeye mahkûm olduğuna işaret edilir.

Amaia'nın yanında büyüdüğü halası Engrasi de güçlü bir kadındır. Elizondo'da yalnız yaşayan, arkadaşlarıyla sık sık poker oynayan ve tarot falı bakan Engrasi, mistik güçlere sahip sıra dışı bir kadındır. Sahip olduğu güçlü sezgileriyle Amaia'yı koruyan ve ona gelecekle ilgili bilgiler veren Engrasi, Clarissa P. Estés’in "bütün içgüdüsel sistemin besleyici kökünü simgeler" dediği yaşlı kadın arketipine benzer: "Bu yaşlı kadın, akılcılığın dünyası ile mitosun dünyası arasında durmaktadır" (2020: 42-44). Engrasi, anlatı boyunca Amaia’yı kötülükten korur ve mitolojik güçlere sığınarak dişil geleneği muhafaza eder. Bask mitolojisi hakkında Amaia'ya bilgiler verir ve sezgileriyle onu yönlendirir. Böylece Bask mitolojisindeki dişi tanrıça Mari ile Amaia arasında etten kemikten bir köprü görevi görür. Engrasi aracılığıyla vurgulanan sezgi, sembolik bir anlam kazanır ve dişil gücü yansıtır. Estés’in içgüdüsel sistemin besleyici kökünü simgelediğini söylediği yaşlı kadın arketipi olarak varlık gösteren Engrasi karakteriyle kültürel ekofeministlerin toplumsal ekolojik anlayışta mitleri ve ruhsallığı ön plana çıkarma hedefleri örtüşmektedir.

Engrasi aracılığıyla ön plana çıkan sezgi ve içgüdü kavramları, erkek yazarlı polisiye roman geleneğinde kadınla özdeşleştirilir. Erkek dedektif saf analitik mantıkla ve profesyonelce olayları çözerken sezgi ve içgüdü kadın cinsiyle özdeşleştirilip değersizleştirilir. Baztán Ü̧̈lemesi’nde bu durum ters yüz edilir. Amaia, soruşturmalarını akılcı yöntemlerle profesyonelce çözer. Çözüm bulamadığı ve tıkandığı zamanlarda akıl almak için FBI'da bulunduğu sırada tanıştı̆̆ özel ajan Aloisius Dupree'ye başvurur. El Guardián Invisible'de seri cinayetlerin soruşturmasında akıl danışmak için Dupree'yi arar. Olayları baştan sonra anlatır ve ondan gelecek ipucunu bekler:

\begin{abstract}
"Dedektif Salazar, çok dedektif tanıyorum ve şüphesiz ki sen hayatımda tanıdığım en iyi dedektifsin. Seni bu kadar iyi yapan şey polis tekniklerini harika bir şekilde uygulaman değil. Buradayken bunu birçok kez konuşmuştuk, hatırlıyor musun? Seni sıra dışı bir dedektif yapan, amirinin seni bu soruşturmanın başına geçirmesine sebep olan şey, sahip olduğun harika iz sürme yeteneğindir. İşte $\mathrm{bu}$, dostum, sıra dıșı dedektifleri sıradan polislerden ayıran şeydir. Bir sürü bilgi verdin, FBI ajanlarının yapacağı gibi öznenin profilini çizdin ve soruşturmada adım adım ilerledin... Ama bana içinden ne hissettiğini söylemedin dedektif, içgüdülerin sana ne söylüyor?” (Redondo, 2017: 317)
\end{abstract}

FBI özel ajanı Dupree, Amaia'nın harika ve çok başarılı bir dedektif oluşunu, onda kendiliğinden hep var olan bir iz sürme yeteneğiyle ilişkilendirir. Sıra dışı dedektifleri sıradan polislerden ayıran bu yetenek, temel içgüdüdür. Bu bağlamda bilimsel verilerin yanı sıra içgüdülere göre hareket etmek dedektifi üstün kılan bir özelliğe dönüşür. Ekibin diğer erkek dedektiflerinden Iriarte aracıllğıyla da sezgilerin ve içgüdünün önemi vurgulanır:

"Bu bir çeşit ilksezi, içgüdüsel bir his gibi, bilirsin ben öyle ilk görüşte edindiğim izlenimle yargıda bulunmam ama seziler benim işimde çok önemlidir. Bence çoğu kez temel bir nedene dayanmadığı için başkalarının bizi kaygılandıran şeylerini görmezden geliyoruz fakat sezdiğimiz ama önemsememeye karar verdiğimiz bu duygu, zaman içinde nedenleriyle yüklü bir şekilde geri döner

\footnotetext{
RumeliDE Dil ve Edebiyat Araşttrmaları Dergisi Osmanağa Mahallesi, Mürver Ciçeği Sokak, No:14/8 Kadıköy - İSTANBUL / TÜRKIYE 34714 e-posta: editor@rumelide.com tel: +90 505 7958124, +90 2167730616 
ve bazılarının sezi, içgüdü, ilk izlenim dediği ve aslında vücut dili, yüz ifadeleri ve küçük yalanlarla desteklenmiș bilimsel temellere dayanan bu șeyi önemsemediğimiz için pişman oluruz." (Redondo, 2017: 382-383)

Özel ajan Dupree ve polis dedektifi Iriarte gibi üçlemenin önemli erkek karakterleri aracllı̆̆ıla daha önce polisiye romanlarda sadece kadınlarla özdeşleştirilerek gündeme gelen ve küçümsenen içgüdü ve sezgi, Baztán Üçlemesỉnde yeniden anlamlandırılmıştır. Son derece başarılı olan ve erkeklerden oluşan bir ekibin başında olan kadın dedektifi sezgiye ve içgüdüye erkek dedektifler yönlendirmektedir. Buna göre bu iki kavram, polisiye roman geleneğinde süregelen cinsiyetçi anlamından arınır. Kadın dedektifi üstün kılan bir ayrıcalık olarak yansıtılır ve kadın/sezgi ilişkisi onaylanarak yüceltilir.

Baztán Üçlemesi, polisiye roman türünün cinsiyetçi yapısının temelini oluşturan Batı felsefesinin kökenini, yani düalist düşünce sistemini sorgulamaya açar. Bu düşünce sisteminin temelinde doğayla özdeşleştirilen ve değersizleştirilen kadın kimliğini yeniden anlamlandırmaya ve kültürel ekofeminist bir yaklaşımla kadının doğayla özdeşleşimine olumlu bir değer yüklemeye çalışır. Kadın/doğa arasındaki süregelen cinsiyetçi ilişkinin farklı bir bakış açısıyla yeniden yorumlanacağına ve ikili ilişkiler ağında verilen değerin tersine çevrileceğine kahramanın adının Bask mitolojisinde geçen dişi tanrıça Mari/Maya (Maya-A/maia) ile benzeşmesiyle daha anlatının başında işaret edilir.

Üçlemede karşımıza çıkan tanrıça Maya veya diğer adıyla Mari, Bask mitolojisinde güneşin, rüzgârın, suyun ve toprağın sahibi ana peridir (Ortiz Osés, 1984: 10). Dişi tanrıça Mari, teke, at, kuzgun, akbaba, firtına, beyaz bulut, gökkuşă̆ı, yanan ağaç veya ateş topu gibi değişik şekillerde ortaya çıkar. Toprağın içinde, büyük ve derin mağaralarda, uçurumlarda, derin yarıklarda ve dar boğazlarda yaşar. Toprağın kişileştirilmiş sembolüdür. Diğer mitolojilerdeki ana tanrıçalarla bağlantılı olan Mari, verimliliğin ve doğurganlığın tanrıçasıdır (Aranzadi, 1981: 2). Aynı zamanda dört âlemin ve dört elementin büyücüsü olarak bilinmektedir (Ceruti, 2011: 36-37). Baskllların sözlü halk geleneklerinden olan ve günümüze kadar ulaşan efsanelerine göre Mari, dağların zirvelerindeki, uçurumlardaki mağaralarda yaşar. Bask mitolojisine göre Amboto dağlarının zirveye yakın yerinde bulunan ve "Mari’nin Mağarası" olarak geçen yer, toprak ananın pagan temsillerinden biri olan tanrıça Mari'nin daimi evlerinden biridir (Panizo Büyükkoyuncu, 2009: 7). Efsaneye göre Mari’nin üçlemede de karşımıza çıkan ve yine kadınlarla özdeşleştirilen lamia ${ }^{11}$, sorgiña/belagile ${ }^{12}$ gibi büyü yapan, erkekleri kandıran veya tuză̆a düşüren yardımcıları vardır (Ceruti, 2011: 38-39). Dolayısıyla üçlemede Bask mitolojisindeki dişi tanrıça ve dişi figürlerin kullanımıyla toprak ana metaforunu yeniden canlandırma girişimi, kültürel ekofeministlerin tarih öncesi dönemdeki doğa ana imgesini yeniden canlandırma amacıyla örtüşür; dişi tanrıça Maya-Amaia benzerliğinden yola çıkılarak kadın dedektif üzerinden kadın kimliğinin çerçevesini belirleyen değerler yeniden tanımlanır. Bunun yanı sıra efsanelerde geçen lamia, sorgiña veya belagile üzerinden femme fatale, tehlikeli veya ölümcül kadın gibi olumsuz şablonlara sokulmaya çalışlan kadın kimliği, Baztán Üçlemesi’nde polis dedektifine yardım eden doğaüstü figürlere

11 Lamialar mağaralarda, kuyularda veya nehirlerde yaşayan dişi yaratıklardır. Ceánuri, Orozco ve Elanchove'de lamianın ufak tefek, alnının ortasında tek gözü olan bir kadın olduğuna inanılır. Genelde çamașır yıkamakla veya taranmakla meşguldürler. Kendilerine adaklar sunulmasını isterler; eğer bir çiftçi lamialar için yiyecek bırakırsa lamialar bu yiyecekleri geceleri yer ve karşılık olarak da çiftlikte yarım kalmış işleri tamamlarlar veya tarlayı ekerler. Lamiaların ortadan kaybolmalarına kimi yerlerde öküzlerin sürüldüğü pulluğun, kimi yerlerde de tenha yerlerde kurulan keşiş kulübelerinin sebep olduğuna inanılır (Barandiaran, 2014: 69-71).

12 Bask mitolojindeki güçlï ve karanlık yanları olan cadı kadın yaratıklardır. Bir diğer anlamları da doğumun bekçisidir; çünkü bebeklerin doğumlarını yöneten yaratıklardır. Geceleri uyanık geçiren bu yaratıklar genellikle mağaralarda yaşarlar. Güçlerini, gece yarısından sabah ilk horoz ötüşüne kadar kullanabilirler. Dişi tanrıça Mari’nin yardımcılarındandır. Mari’nin emirlerini yerine getiren bu yaratıklar inanışa göre Paīs Vasco'daki çok eski köprüleri inşa edenlerdir. Hristiyan keşiş kulübelerinin kurulmaya başlanmasıyla birlikte yok olmaya başladıklarına inanılır (Barandiaran, 2014: 72-76).

RumeliDE Dil ve Edebiyat Araștırmaları Dergisi Osmanağa Mahallesi, Mürver Ciçeği Sokak, No:14/8 Kadıköy - ÍSTANBUL / TÜRKIYE 34714 e-posta: editor@rumelide.com tel: +90 $5057958124,+902167730616$
Address

RumeliDE Journal of Language and Literature Studies

Osmanağa Mahallesi, Mürver Çiçeği Sokak, No:14/8

Kadıköy - ISTANBUL / TURKEY 34714

e-mail: editor@rumelide.com,

phone: +90 $5057958124,+902167730616$ 
dönüşerek erkek bakışının yarattı̆̆ı anlam tersine çevrilir. Böylece anaerkil toplumun izlerini silmeye çalışan ataerkil toplumun efsanelerde, mitlerde kısacası kültürü şekillendiren bütün kaynaklarda kendi çıkarlarını koruyacak şekilde betimledikleri kadın kimliği ters yüz edilir.

Kahramanın adı gibi soyadı da (Salazar) belirli bir anlam çerçevesinde kurgulanmıştır. Üçlemede sık sık Orta Çă̆’da cadı olarak suçlanıp Engizisyon mahkemeleri tarafından yakılarak öldürülen kadınlardan bahsedilir. Fatmagül Berktay, Barbara Ehrenreich'in Cadılar, Büyücüler ve Hemşireler adlı kitabının son sözünde Batı'da etimolojik ve tarihsel olarak kadın, cadı, ebe ve şifa verici kelimelerinin birbiriyle bağlantılı olduğuna işaret eder ve Orta Çağ'da şifa veren kadınlara olumsuz anlamda cadı sıfatının takıldığından bahseder (1987: 73-74). Kayıtların incelenmesi sonucunda cadı olarak yakılanların büyük bir kısmının kadın olduğu ortaya çıkar. "Kimlerin cadı olarak damgalanıp katledildiğine baktığımızda, bunların kendine güvenen ve bağımsız hareket edebilen güçlü kadınlar oldukları anlaşılıyor" (Berktay, 1987: 75). Böylece erkekleri, güçleri ve bağımsızlıklarıyla tehdit eden kadınların cadılıkla suçlanıp yakıldıkları gerçeği ortaya çıkar. Dolores Redondo da aynı şekilde bir röportajında erkeğin himayesi altında yaşamak istemeyen, ormanda tek başına yaşamayı tercih eden veya toplumdan uzak kalmak isteyen kadınların cadı olarak damgalandıklarından bahseder. Bu kadınlar, kendi hayatları ve bedenleri hakkında kendi başlarına karar almak istemiş bağımsız kadınlardır. Bu nedenle Redondo’ya göre Avrupa toplumunda cadı analizinin, kadının bağımsızlı̆̆ının temeli olarak, hak ettiği yere konması gerekir (Sainz Borgo, 2019). Fakat dikkati çeken asıl önemli nokta, cadılık bahanesiyle öldürülen bu kadınların aslında Kilise'nin ileri sürdüğü gibi şeytanla işbirliği içinde olmaktan dolayı değil, Hristiyanlık öncesi kadının değerli olduğu ve saygı gördüğü pagan inançları sürdürüyor olmaları, özetle doğaya tapıyor olmalarından dolayı cezalandırıldıkları gerçeğidir:

"Kilise konseyleri, bu dönemde cadılık inancını kâh salt batıl inanç ve paganlık kalıntısı olarak görüyor, kâh bastırılması gereken güncel ve gerçek bir tehdit olduğunu ilan ediyorlardı. Kilisenin bu dönemdeki esas uğraşı, eskil pagan inanç ve pratiklerinin zayfllatılması ve Kilisenin otoritesini zayıflatan "sapkınlığa" karşı mücadele edilmesiydi. Bir anlamda günümüzün "kurtuluş teolojisi"ne benzetilecek sapkın hareketler, kurulu toplumsal düzenin yıkılmasını ve yerine daha eşitlikçi bir düzen geçirilmesini öneriyorlardı.” (Berktay, 2010: 58)

Orta Çağ’da kadınların cadılıkla suçlanarak yakılıp öldürülmelerine üçlemede sık sık yer verilmesi, anlatının temelindeki kadın/doğa ilişkisi üzerinden hedeflenen amaçla örtüşür. "Bilinen medeniyetlerin varlığından asırlar önce birçok toplum toprak ananın varlığına inanıyor ve anaerkil bir toplum düzeni içinde yaşıyordu" (Uçar Özbirinci, 2012: 7). Barışçıl yapıdaki anaerkil dönemde doğurganlığından ve verimliliğinden dolayı kadın ve doğa kutsal kabul ediliyordu. Toprağa bağımlı olmayan, güneş ve gökyüzüyle özdeşleştirilen bir tanrıya tapan ataerkil toplumun anaerkil toplumu ele geçirmesiyle birlikte başlayan süreç, anaerkil toplumun izlerini silmeye çalışarak bugünlere kadar gelir. "Ataerkil düzen gücünü korumak için kadını ezmiş ve yine toplumları bir arada tutan mitlerde, destanlarda, efsanelerde ve masallarda kadını kendi amaçları doğrultusunda tekrardan yazmıştır" (Uçar Özbirinci, 2012: 8). Baztán Üçlemesi bu bağlamda akıl/beden, kültür/doğa, erkek/kadın, eyleyen/kaynak, bütün/parça, Tanrı/insan gibi uzayıp giden ikilikler ağını sorunsallaştırarak polisiye roman türünün cinsiyetçi yapısının köklerini sorgulamaya açar.

160o'lü yıllarda İspanya'da Alonso de Salazar isimli bir Engizisyon sorgucu rahip, büyücülükle ve cadılıkla suçlanıp yakılacak olan birçok kadının hayatını kurtarır. Salazar sayesinde İspanya, diğer Avrupa ülkelerinden daha erken bir dönemde cadı avcılığına son verir. Salazar sayesinde cadı avı resmi olarak tamamen yasaklanmaz fakat suçlanan kişiler hakkında net kanıtlar talep edilir ve suçlamanın gerçek olup olmadığı hakkında araştırma yapılması zorunlu hale gelir. 1609-1623 yılları arasında Logroño'da sorguçluk yapan Salazar, yaptı̆̆ derin araştırmaların sonucunda Bask bölgesinde cadılığın 
olmadığını ileri sürer (Henningsen, 1978: 581-582). Dolayısıyla rahip Salazar, aslında yüzyıllar önce doğaya ve doğal olarak kadının gücüne inanan insanların savunuculuğunu yapmasından dolayı anlatı için önem kazanır. Cadıların avukatı olarak bilinen sorguç Salazar’a benzer şekilde ama farklı bir yolla polis dedektifi Amaia Salazar da aynı soruna karşı savaşır. Üçleme boyunca Amaia ve "modern dedektif" olarak nitelendirilen rahip Salazar arasında sık sı ilişki kurulur. Rahip Salazar'ın bir sene boyunca Baztán vadisinde yerel halkla birlikte yaşayıp, gözlemler yaparak bu bölgede satanizm veya büyücülük gibi şeylerin olmadığını, Baztán'da yaşananların farklı bir tabiattan kaynaklandığını belirtmesinden bahsedilir (Redondo, 2017: 316; Redondo, 2016b: 94-95). İşaret edilen bu farklı tabiat, anlatıda kadın dedektifin düzeni sağlamak için savaştığı ataerkil sistem olarak karşımıza çıkar. Üçlemedeki suçlular, kötülüğe hizmet eden karanlık güçlerden maddi ve manevi güç almak adı altında genç kızları, kadınları ve kız bebekleri kurban eden erkek egemen bir tarikattır. Kadınların delirmelerine sebep olan, tehditle korkutup sindiren, kullanan ve öldüren bu tarikat mizojinist bir yapıdadır. Bu nedenle soruşturmanın başına kadın polisin getirilmesi onları daha da huzursuz eder ve kahramanın kendi ailesini de çemberin içine sokarlar. Polis dedektifinin annesini hastaneden kaçırırlar, onu dedektife karşı bir silah olarak kullanırlar ve sonunda intihar etmesine sebep olurlar. Dolayısıyla yüzyıllar önce rahip Salazar'ın mücadele ettiği şeyin devamı olarak kurgulanan "suçlu" ataerkil sistemin karşısında şimdi bir kadın Salazar durmaktadır.

Ana Dolores Verdú Delgado, feminist teologlar ve ekofeministler arasındaki ilişkiye değindiği makalesinde, kadın gücüne dayanan eski dini sembollerin kadınların psikolojik bağımsızlığına ve cinsiyetler arasındaki eşitliğe teşvik etmesi ihtimalini taşımasından dolayı dişi tanrıçaların, kadınların kendi değerlerini doğrulama ve iyileştirmede dişil arayışın bir parçası olarak tekrar ortaya çlktıklarından bahseder (2012: 76-77). Aynı makalede feminist teolog Ivone Gebara'nın da sözlerine yer verir ve dişi tanrıçalar aracılığıyla köklere dönmekle bir yeniden doğuşa işaret edildiğinden bahseder: "Anne rahmine, toprağa geri dönmek ve oradan bütün kardeşlik için temel şart olan ilkel enerjiyi dışarı çıkarmak zorundayız” (Verdú Delgado, 2012: 78). Bu bağlamda Baztán Üçlemesi’nde karşımıza çıkan dişi tanrıça Mari, orman, nehir ve anne rahmine dönüşe işaret eden mağara metaforlarıyla kadın kimliğinin yeniden doğuşunun, diğer bir deyişle yeni bir kadın kimliği yaratmanın yolları aranmaktadır.

Amaia'nın El Guardián Invisible'de soruşturma nedeniyle doğduğu topraklara, Elizondo'ya dönmesi, kadın kimliğinde yeniden doğuş için zorunlu olan köklere dönme yolculuğunda sembolik bir anlam kazanır. Üçlemede laytmotif olarak karşımıza çıkan mağara metaforu da köklere dönüşe işaret eder. Bask mitolojisinde dişi tanrıça Mari'nin mağaralarda yaşadığına inanılır. El Guardián Invisible'de Mari'nin hamile kalmak için adak sunulan mağarasına çıan Amaia, Legado en los Huesos'da FBI özel ajanı Dupree'nin yönlendirmesiyle soruşturmanın düğüm noktasını çözmesi için tekrar aynı mağaraya yönlendirilir:

“-Görünenden çok daha fazlası olduğunu hissediyorum Dupree, ama işin kötüsü şu ki nereden başlayacağımı bilmiyorum.

-Evet, biliyorsun dedektif Salazar; başlayacağın nokta...

- Başlangıç - diye Amaia tamamladı cümleyi bıkkınlığını ifade ederek.

-Hayır - diye kesti sözünü Dupree kuru bir şekilde.

- Bedenin bir parçasının kesildiğini bildiğim ilk cinayet buydu, öncesinde benzer şekilde başka cinayetler de olabilir ama... onun babası... katili, intihar etmeden önce bana bir not biraktı ve soruşturmayı başlatan bu oldu.

-Tamam ama başlangıcı neydi? Diye tekrar sordu Dupree neredeyse fisıltıyla.

\begin{tabular}{|c|c|}
\hline Adres & Address \\
\hline DE Dil ve Edebiyat Arc & RumeliDE Journal of Language and Literature Studies \\
\hline No & okak, No:14/8 \\
\hline $\begin{array}{r}\text { Kadıköy - İSTANBUL / TÜRKIYE } 34714 \\
\text { e-posta: editor@rumelide.com } \\
\text { tel: +90 } 5057958124,+902167730616\end{array}$ & $\begin{array}{l}\text { Kadıköy - ISTANBUL / TURKEY } 34714 \\
\text { e-mail: editor@rumelide.com, } \\
\text { phone: +90 } 5057958124,+90216773 \text { o } 616\end{array}$ \\
\hline
\end{tabular}


Amaia ürperdi ve Mari’nin mağarasına giden dar patika yola geçtiği sırada yağmurluğunu çizen dikenli çalıları hisseder gibi oldu. Altın bilekliklerinin çınlaması, beline kadar inen altın sarısı uzun saçları, bir kraliçenin veya bir cadınınkine benzer yarım gülüşü ve sesi: "Şuradaki mağaralardan birine elinde bir paketle giren ama eli boş çıkan bir adam gördüm” (...)

-Gördün mü nasıl da bildin. Şimdi Baztán’a geri dönmen lazım.

Amaia birden şaşırdı.

-Aloisius, iki gündür zaten buradayım.

-Hayır dedektif Salazar, hala geri dönmedin.” (Redondo, 2016: 172-173)

Sürekli yağmurun yağdığı, ormanların, nehirlerin ve mağaraların hâkim olduğu Baztán bölgesi anlatıyla bütünleşerek dişil gücün metaforu haline gelir. Dolayısıyla Dupree'nin israrla vurguladığı "Baztán’a geri dönmek" ifadesi de köklere dönüşe işaret ederek sembolik bir anlam kazanır.

Amaia, Mari’nin mağarasına ilk çıkışında mağaranın önünde adının Maya olduğunu söyleyen esrarengiz bir kadınla tanışır. Kadın, eliyle uzaktaki mağaralardan birini işaret ederek bir adamın oraya elinde bir paketle girip paket olmadan çıktığını söyler. Soruşturmanın düğüm noktasını oluşturan o mağarada, soruşturmanın ilerleyen günlerinde öldürülen kadınların kesilmiş kolları bulunur ve işlenen bütün cinayetlerin birbiriyle bağlantılı olduğu ortaya çıkar. Amaia, kesilen kolların kimlere ait olduğunu tespit etmek için bölgede işlenen kadın cinayetlerini araştırmak ve bu kadınların kimliğini tespit etmek zorunda kalır. İşlenen bu kadın cinayetlerinin hepsinde kolların kesik olmasının daha önce nasıl fark edilmediğine şaşırır. Yardımcısı polis dedektifi Jonan, kadın cinayetlerinin üzerinde çok durulmadan hızlıca dosyaların kapandığını, hele de katilin itirafından veya intiharından sonra bu sürecin çok daha hızlı gerçekleştiğini söyler: "Bu kapalı bir konu ve ailelerin hissettiği utanç onların sadece susmalarına yarıyor” (Redondo, 2016: 199). Dupree'nin Amaia'yı yönlendirdiği, davayı çözmesi için dönmek zorundasın diye ısrarla vurguladığı başlangıç, dişil gücün; mağarada bulunan bedenlerinden ayrılmış kadın kolları ise bütün/parça ikiliğinde kadını temsil eden taraf olan "parça"nın yani kimliksizleştirilen, ötekileştirilen ve sessizliğe mahkûm edilen kadınların alegorisine dönüşür.

El Guardián Invisible'de halasının ve kız kardeşinin anlattıklarından etkilenip görmek amacıyla çıktı̆̆ı, Legado en los Huesos'ta ilkinde soruşturmanın bir parçası olarak sonrasında annesinin elinden oğlunu kurtarmak için gittiği mağara, Ofrenda a la Tormenta'da anne rahmine geri dönüşün metaforu olarak karşımıza çıkar.

\begin{abstract}
"Mağaranın dışı ve karanlık ağzı birkaç metre yukarıda; tamamını oradan göremiyordu. Solunda yanıltıcı bitki örtüsüyle kaplı dik ve derin uçurumun; arkasında geldiği patika yol ve sağında taştan, üstü boş adak masası. (...) Yalnızlıkla kuşatılmış bir halde etrafına bakındı. Eğildi ve yumuşak zeminden biçimsiz bir kenarı söktü. Kıyafetine sürerek üzerindeki çamuru temizledi ve iki adım ilerleyip temiz taş masanın üzerine yerleştirdi. Sonrası yok. (...) Yüzü sırılsıklam öylece hareketsiz bir şekildeyken gözlerindeki ağır yağmur damlalarının keskinliğini hissetti... Amaia Salazar kafasını eğdi. Vücudu, mağlup olmuş bir şekilde öne doğru çökerken kirpiklerinde asılı kalan damlalar gözyaşı okyanusuna sürüklenerek düştü. Dizlerinin üzerinde kaydı. Yüzü taşa yapışmış bir halde elleriyle gözlerini kapatarak masanın üzerine yı̆̆ıldı. (...) Ne zeminin sertliğini ne de su ve çamurdan sırılsıklam olmuş pantolonunu hissediyordu. Anne kucağı gibi yüzünü içine sokmaya çalıştığı kayadan gelen mineral kokusunun farkında değildi. Ama en eski kutsanma ve teselli hareketi olan, başının üzerinde duran o yumuşak ve sıcak eli hissediyordu.” (Redondo, 2016b: 249)
\end{abstract}

Toprak kökenli mağara anne rahmini temsil eder. İnsanın doğadaki ilk evi olan, can veren ve koruyan mağara, kadına ait bir yerdir. Mağaranın topraktan oluşu ise kökene dönmeye işaret eder. "Yeni bir üye bu tapınağa karanlığın ve içedönük bilgeliğin sesini duymak için gelir” (Gilbert\&Gubar, 2016: 147). Amaia da yenik düştüğünde, başarısız olduğunda, anne rahmini andıran mağaraya sığınır. Annenin

Adres
RumeliDE Dil ve Edebiyat Araştirmaları Dergisi Osmanağa Mahallesi, Mürver Çiçeği Sokak, No:14/8 Kadıköy - İSTANBUL / TÜRKIYE 34714 e-posta: editor@rumelide.com tel: +90 $5057958124,+902167730616$
Address

RumeliDE Journal of Language and Literature Studies

Osmanağa Mahallesi, Mürver Çiçeği Sokak, No:14/8

Kadıköy - ISTANBUL / TURKEY 34714

e-mail: editor@rumelide.com,

phone: +90 5057958124 , +90 2167730616 
rahmindeki bir bebek gibi ıslak ve çamurlu haliyle kayanın üzerine uzanır ve kendini, toprak ananın şefkatine teslim eder. Amaia'nın köklerine döndüğü, sığındığı ve cevap aradığı mağara, metaforik olarak öz benliğe, dişil güce işaret eder. "Böylelikle, erkek yazar gecenin bir vakti dünyanın sınırına doğru gider ve balinanın karnına ulaşır ya da karanlığın ejderhalarını kesmeye veya onlar tarafindan kesilmeye doğru yol alırken, kadın yazar da Adrienne Rich’in "kadın hafızasının krater açılmış gecesi" adını verdiği yere doğru, bu karanlığ yeniden canlandırmak, kaybedenleri geri getirmek, yeniden yaratmak, hamile kalmak ve doğurmak için yola düşer" (Gilbert\&Gubar, 2016: 153).

Polisiye romanda bozulan toplum düzeni, Baztán Üçlemesỉnde bozulan doğa düzeni olarak ifadesini bulur. Doğanın bozulan dengesiyle işaret edilen ise anaerkil toplumu tahakküm altına alarak kadını kimliksizleştiren, ikilikler ağında doğanın karşısında durup kültürle özdeşleşen ataerkil toplumdur. $E l$ Guardián Invisible'de nehir kenarına bırakılan genç kız cesetleri, Legado en los Huesos'ta mağarada bulunan bedeninden ayrılmış kadın kolları, Ofrenda a la Tormenta'da mahzen mezarda bulunan kurban edilmiş kız bebeklerinin kemikleri, erkek egemenliği karşısında aşağılanan ve parçalanan kadın kimliğini temsil etmektedir. Dolayısıyla bu cansız kadın bedenlerinin bulunduğu nehir, mağara ve yer altındaki mahzen dişil güce işaret eden anne rahminin metaforlarına dönüşür. Parçalara ayrılmış, tanınmaz hale gelmiş, kimliksizleşmiş bu kadın bedenlerinin kimlere ait olduğunu bularak onlara sembolik anlamda yeniden kimlik kazandıran polis dedektifi Amaia Salazar'dır. Böylece Amaia, başından beri işaret edilen, dişil gücün, dişil enerjinin sahibi toprak ana, dişi tanrıça Mari ile bütünleşir. Anlatıda bu özdeşleşme Engrasi'nin cümleleriyle de ifade edilir:

\begin{abstract}
"Bu, senden büyük bir özveri ve saygı bekleyerek seni savaşa iten talepkâr rahibe. Sana hayranlık duyuyor ve düşmanlarına karşı seni bir silah olarak kullanacak. Onun için bir silahtan, dengeyi sağlamak adına eski çağlarda verdiği savaşta onun hizmetinde kötülüğe karşı yolladığı bir askerden başka bir şey değilsin. Canavarların, yüzyıllardır vadinin derinliklerinde uyuyan güçlerin uyanmasına izin veren korkunç bir eylemle bozulan ve şimdi bastırılmasına yardım etmek zorunda olduğun denge. (...) O ne iyi ne kötü; doğanın gücü, adil denge, toprak ananın kendisi kadar zalim ve acımasız olabilir." (Redondo, 2016: 210)
\end{abstract}

Üçlemede Amaia'nın içinden geçip anne rahminin metaforu olan mağaraya gitmek için kullandığı, bazen birden içine dalıp güç aradığı yer olan orman da dişil sembollerden biridir:

\begin{abstract}
“İnsanlar tarafından uğradığı değişimden önce dağlarında kayın ağaçları, alt kesimlerde meşe ağaçları, ortalarında fındık, alıç ve kestane ağaçlarıyla kaplı olan büyük Baztán ormanı, şimdi neredeyse tamamen diğer ağaçların arasında despot bir şekilde hüküm süren kayın ağaçlarıyla kaplı. (...) Ormanın büyüklüğü onda korku ve sersemlik yaratsa da her zaman ait olma hissi uyandıran gizli bir gurur kaynağıydı. Onu sevdiğini biliyordu ama onun sevgisi, uzaklıkta ve sessizlikte beslenen saygılı ve bakir bir aşktı.” (Redondo, 2017: 85)
\end{abstract}

İnsanın ilk başlarda karşısında savunmasız kaldığı ve taptığı doğanın zamanla tahakküm altına alınmasına benzer şekilde doğayla özdeşleştirilen kadın da aynı şekilde ötekileştirilir. Baztán ormanının yapısını değiştiren insan tahribi vurgusuyla bu erkek egemen tahakküm sistemine işaret edilir. Fakat Amaia için orman, hala aitlik hissi duyduğu gizli bir gurur kaynağı olarak orada durmaktadır. Ağaçlar ve orman, üçlemedeki diğer dişil sembol ve metaforlar gibi öze dönüşe, öz benliğe işaret ederler. "Uzaklıkta ve sessizlikte beslenen aşk" ifadesiyle kadının kültür içinde özünden, içgüdülerinden, kısacası kendi kimliğinden uzaklaşması ifade edilmekte ve orman metaforuyla bu öze dönüşün sağlanması amaçlanmaktadır. Clarissa P. Estés, ormanı, kadının geriye dönüşünün, "evine dönüşünün” araçlarından biri olarak ele alır: "Ev, yağlanmış yatağında kayan bir eklem kadar kolay çalışan, bozulmamış içgüdüsel hayattır, orada her şey olması gerektiği gibidir, bütün gürültüler kulağa haklı görünür; ışık güzeldir; kokular bizi alarma geçirmez, tersine sakinleştirir” (2020: 315). Doğa

RumeliDE Dil ve Edebiyat Araştırmaları Dergisi Osmanağa Mahallesi, Mürver Ciçeği Sokak, No:14/8 Kadıköy - ÍSTANBUL / TÜRKIYE 34714 e-posta: editor@rumelide.com tel: +90 $5057958124,+902167730616$
Address

RumeliDE Journal of Language and Literature Studies

Osmană̆a Mahallesi, Mürver Çiçeği Sokak, No:14/8

Kadıköy - ISTANBUL / TURKEY 34714

e-mail: editor@rumelide.com,

phone: +90 5057958124 , +90 2167730616 
karşısında erkeğin "zaferi” olarak karşımızda duran kültür içinde öz benliğine yabancı düşen kadın için orman, Estés’in deyimiyle besleyici bir iç dünyaya dönüşür:

\begin{abstract}
“Orada sadece derin düşünceye değil öğrenmeye de; unutulmuş, kötüye kullanılmış ve gömülmüş olanı açığa çıkarmaya da zaman vardır. Orada geleceği hayal edebilir ve psişenin yara izlerinden oluşan haritalarını gözden geçirerek neyin neye yol açtığını ve daha sonra nereye gideceğimizi öğreniriz." (2020: 315)
\end{abstract}

Orman, kadını kısıtlandığı domestik alandan kurtaran özgürlük alanıdır. Kadının asıl evidir; bir sığınaktır. Amaia için annesi tarafından kaçırılan oğlunu ararken bir rehbere dönüşür. Oğlu kaçırılınca Amaia, yardımcısı polis dedektifi Jonan ile birlikte içgüdülerinin yönlendirmesiyle koşar adım ormanın içine dalar. Orman, Amaia'nın içini rahatlatan bir güce sahiptir. Ormanın derinliklerinde koşarken birden durur. Jonan elindeki feneri etrafta gezdirir ve kaybolduklarını söyler. Şimdiye kadar çıkmış olmaları gereken yol gözükmemektedir. Amaia birden karanlığa doğru döner ve "Yardım et bana!" diye haykırır (Redondo, 2016: 536). Jonan'ın tuhaf bakışlarına aldırmadan ormanın derinliğindeki karanlıktan tekrar çaresizce yardım ister. Jonan elindeki feneri yere indirir ve şaşkın bir şekilde Amaia'nın ne yapmak istediğini anlamaya çalışır. Amaia dua eder gibi gözlerini kapatır ve olduğu yerde sessizce bekler. Tam o anda bir ıslık sesi duyulur; ıslı̆̆ın sesi o kadar yakından ve güçlü bir şekilde gelir ki Jonan korkudan elindeki feneri yere düşürür. Amaia'nın daha önce dişi tanrıça Mari’nin mağarasından aşağı inerken duyduğu ıslıkla aynı olan bu ses, Bask mitolojisindeki Basajaun'un sesidir. ${ }^{13}$ Ormanın koruyucu gücü olan Basajaun'un tehlike anında sslık çalarak insanları uyarıp tehlikeyi haber verdiğine inanılır. Anlatıda Amaia'ya yardım eden doğal bir güç olarak kullanılan motiflerden birine dönüşür. Basajaun'un ıslığını duyar duymaz Amaia’nın çaresizliği yerini kararlılığa bırakır ve bir yöne doğru kendinden emin bir şekilde tekrar koşmaya başlar. Basajaun'dan geldiğine inanılan kısa ıslıkları takip ederek ormandan çıkış yoluna ulaşmayı başarır. Amaia, ormanın sakinleştirici gücü ve doğanın koruyucu gücü olan Basajaun sayesinde yolunu bulur ve ormanı geçip mağaraya giderek oğlunu annesinin elinden kurtarır. Bu bağlamda orman ve doğanın koruyucu güçleri sayesinde yolunu bularak oğlunu kurtarması sembolik bir anlam kazanır. Amaia, Estés’in deyimiyle "evinin yolunu bulabilmeyi” başarmıştır.

Üçlemede laytmotif olarak karşımıza çıkan dişil sembollerden biri de Baztán nehri ve sık sık yağan yağmur aracılığıyla işaret edilen sudur. Greta Gaard, yaradılış mitlerini ileri sürerek kadın, su ve doğanın iç içe olduğunu açıklar ve bunları, yaradılışın kutsal kaynakları olarak değerlendirir. Aynı şekilde Hristiyanlık öncesi pagan kültürlerde doğa anaya geçişin sağlandığına inanılan kuyuların varlı̆̆ından söz eder (2001: 160). Kadına ve doğaya olduğu gibi suya yüklenen olumlu anlam ve kutsallık zaman içerisinde değerini kaybeder. Hristiyanlıkla birlikte yeni doğan bir bebeğin temiz sayılması için vaftiz edilmesi gerekir. Bu, kadının bebeğine hayat veren, içinde taşıdığı suyun kirli olduğu anlamına gelir. Amaia'nın rüyasında, betimlerden efsanede geçen dişi tanrıça Mari'nin yardımcılarından olduğu anlaşılan sivri dişli, ördek ayaklı lamialar hep bir ağızdan Amaia'dan "Nehri temizle!" "Suçu temizle!" şeklinde istekte bulunurlar (Redondo, 2016b: 253). Nehrin kirlenmesiyle vurgulanmak istenen, doğayla birlikte değersizleştirilen kadın kimliğidir. Kadınları öldürüp kollarını kesip mağaraya atan, genç kızları öldürüp nehir kenarına bırakan, kız bebekleri öldürüp yer altı mahzenine koyan erkek egemenliğini temsil eden tarikatın sorumlularını yakalamasıyla Amaia, nehri temizlemiş olur. Su, mağara metaforu gibi öze dönmeyi, hayat vermeyi ve yeniden yaratmayı sembolize

Ormanın efendisi olan Basajaun, ormanın derinliklerinde veya herkesçe bilinen yerlerdeki mağaralarda yaşayan Bask mitolojik figürlerinden biridir. İnsana benzer bir yapıda olan Basajaun, tüylerle kaphıdır. Sürülerin koruyuculuğunu yapar. Fırtına öncesi çaldığı ıslıkla çobanları yaklaşan tehlikeye karşı uyarır. Bulunduğu veya yakınlarında olduğu ağıllarda kurtlar sürüye yaklaşamazlar. Bazen korkunç olarak tasvir edilse de bazen de insanların tarımı, demirciliği ve değirmenciliği öğrendiği kişi olarak yansıtılır (Barandiaran, 2014: 76-77).

Adres $\mid$ Address

RumeliDE Dil ve Edebiyat Araşttrmalar Dergisi $\quad$ RumeliDE Journal of Language and Literature Studies Osmanağa Mahallesi, Mürver Çiçeği Sokak, No:14/8 Osmanağa Mahallesi, Mürver Çiçeği Sokak, No:14/8 Kadıköy - İSTANBUL / TÜRKIYE 34714 Kadıköy - ISTANBUL / TURKEY 34714 e-posta: editor@rumelide.com

e-mail: editor@rumelide.com

tel: +90 505 7958124, +90 2167730616 phone: +90 505 7958124, +90 2167730616 
ederek kadının özündeki güce işaret eder. Suyun doğaya hayat vermesi ile kadının insanlığa hayat vermesi benzeştirilir. Bu benzeşim Amaia'nın oğlu Ibai'yi doğururken uykuyla uyanıklık arasında gördüğü rüyayla da vurgulanır:

“-Hiçbir şey yapamıyorum! Diye bağırdı deliye dönmüş bir şekilde.

-Nehri temizle! Diye bağırdı seslerden biri.

- Nehir.

- Nehir.

-Nehir. Diye hep bir ağızdan bağırdı diğerleri.

Ümitsiz bir şekilde sudan yükselen haykırışların nereden geldiğini anlamaya çalıştı. Baztán'ın kapalı gökyüzü, çıkıntılı kayaların üzerinde oturmuş uzun saçlarıyla oynayıp, iğne keskinliğindeki dişleri ve kalın kırmızı dudaklarından şiddetle fişkıran ayini tekrarlarken bir yandan da ördek ayaklarını suyun üstüne vuran kadınları aydınlatan gümüsş rengi ay ışığının geçmesine izin verecek kadar açıldı.

-Nehri temizle.

Nehir, nehir, nehir." (Redondo, 2016: 46)

Kadın/su benzeşimi üzerinden kadın/doğa ilişkisine olumlu bir anlam atfedilir. Dolayısıyla nehir, Amaia’nın Baskçada “nehir” anlamına gelen Ibai adını verdiği oğlunu doğurmasıyla temizlenir. Bu bağlamda annelik, feminist polisiye roman geleneğinde dişil güce işaret ederek yeni bir anlam kazanır. Kadın dedektif kimliğini içkinlikten aşkınlığa taşır. "Bebeği karnında büyümeye, korkusunu isimlendirmeye cesaret edip onu James ile paylaşmaya başladığından beri (...) yıllarca sonsuza kadar kaybettiğini sandığı güvene, toprak, kök ve yuva hissine sahip olduğunu anlamıştı" (Redondo, 2016: 21). Annelik, vücudun içindeki doğal, yaratıcı ve canlı gücü deneyimleme isteği olarak tanımlanır. Üçlemede aynı zamanda anneliğin idealleştirilmesi ve ataerkil zihniyet tarafından sınırlarının çizilmesi de eleştirilir. Amaia, Mari'nin mağarasından dönerken yola aniden çıkan hamile genç bir kadına tam çarpmak üzereyken yolun ortasında durur. Kadına yardımcı olmak ve evine bırakmak için arabasına alır ve sohbet etmeye başlarlar:

“-Peki anneliğe ve hamileliğe nasıl uyum sağlıyorsunuz? Böyle bir soru soruyorum çünkü ben mesleğimle iyi bir anne olmayı birleştirme konusunda çok güçlük çekiyorum.

Kızın onu nasıl kararllıkla izlediğini fark etti.

-Görünüşe göre siz de onlardan birisiniz?

(...)

- Ne demek istediğinizi anlamadım?

-Hani şu nasıl anne olunacağına başkalarının karar vermesine izin veren kadınlardan biri. (...) Bakın, annelik son derece içgüdüsel ve doğal bir şeydir, o kadar kural, kontrol ve tavsiye çoğu zaman anneleri sadece bunaltır.

-İyi bir anne olmak için endişelenmek normal - diye cevapladı.

- Tabii ki ama bu endişe daha fazla kitap okumakla ortadan kalkmayacak. Siz beni dinleyin Amaia, siz o küçük için en iyi annesiniz (...).

-Görünüşe bakılırsa bu konuda uzmansinız.

-Öyleyim; tıpkı sizin gibi.” (Redondo, 2016: 442-443)

Genç kadının arabadan indikten sonra oturduğu yere bıraktığı cevizden onun aslında Mari’nin yardımcılarından biri olan belagile olduğu anlaşılmaktadır. İnanışa göre ceviz, belagilenin gücünü sembolize eder (Redondo, 2016: 376). Amaia ve hamile genç kadın arasında geçen diyalog, anneliğin

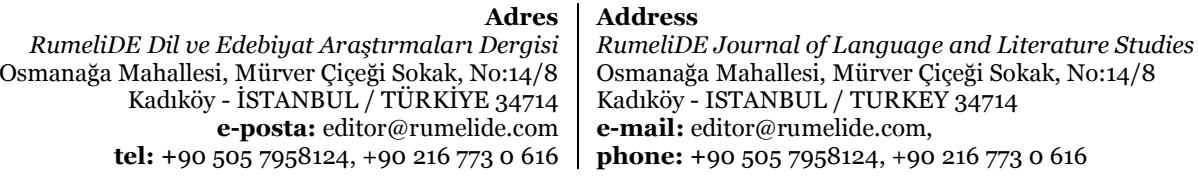


içgüdüsel olarak kadının doğasına uygun olduğu görüşünü doğrular. Her kadının bu bilgiye doğuştan sahip olduğu vurgulanır ve ataerkinin anneliğin sınırlarını belirleyişi eleştirilir. Böylece bir kere daha kadın/doğa benzeşimi onaylanır ve annelik üzerinden yüceltilir. Buna göre polisiye roman geleneğinde de bir sapma söz konusu olur ve annelik ve dedektiflik kimliği kadın dedektif için bütünleşir.

\section{Sonuç}

İspanyol yazar Dolores Redondo tarafından 2013-2014 ylları arasında yazılan Baztán Üçlemesi, polisiye roman türünün cinsiyetçi yapısının temelini oluşturan düalist düşünce sistemini sorgulamaya açar ve bu ikilik ağında doğayla özdeşleştirilip tahakküm altına alınan kadın kimliğini yeniden anlamlandırmaya ve kadın kimliğine olumlu bir değer yüklemeye çalışır. Buna göre üçlemenin kadın dedektifi Amaia Salazar, erkek polislerden oluşan bir ekibin başındadır ve FBI eğitimiyle onlardan çok daha tecrübeli ve başarılıdır. Erkek polislerin çözemedikleri davaları bile çözüme kavuşturarak polisiye romanın akılla özdeşleştirilen erkek dedektif figürünü yerinden eder. Bunu yaparken erkek dedektiflere öykünerek onlardan birine dönüşmez. Dedektiflik ve kadınlık kimliği arasında bir mücadele vermez. Polisiye roman geleneğinde bir erkek pozisyonu olarak görülen dedektiflik mesleğini sürdürürken kadının doğaya benzeşiminde başat rol oynayan annelik kimliğine de sahiptir. Anlatı boyunca ön plana çlkarılan ve Amaia Salazar kurgusunu polisiye roman geleneğinde farklı bir noktaya taşıyan kadın/doğa benzeşimi vurgusu, Amaia ile özdeşleşen dişi tanrıça Mari ve dişil gücü sembolize eden orman, nehir ve mağara alegorileri ile sağlanır. Bunların yanı sıra çağdaş dönem İspanyol edebiyatında kadın yazarlı polisiye romanlarda kadın dedektif için bağımsızlığını kısıtlayıcı kavramlar veya kadın dedektifin şüpheyle yaklaşıp kimliğiyle bütünleştiremediği kavramlar olarak karşımıza çıkan evlilik ve annelik, Baztán Üçlemesi’nde dedektifin kimliğini tamamlayıcı unsurlara dönüşür. Buna göre evlilik ve annelik, polisiye roman geleneğinde ataerkinin uzantısı olmaktan çıar. Kadın dedektif evlilikle birlikte mesleğini yarıda bırakmaz, aksine mesleğinde zorlandığı zamanlarda maçoluktan ve despotluktan uzak yeni maskülen karakterdeki kocasından ve kendi kadınlık tabiatından güç alır. Sezgi ve içgüdü kavramları polisiye roman geleneğinde kadın cinsiyle özdeşleştirilip değersizleştirilirken Baztán Üçlemesi’nde yeniden anlamlandırılır. Soruşturmalarını mevcut prosedürler çerçevesinde profesyonelce yürüten Amaia Salazar, FBI özel ajanı bir erkek polis tarafından sezgi ve içgüdüye yönlendirilir. Sezgi ve içgüdü, dedektifi üstün kılan özellikler olarak ön plana çıkarak polisiye roman geleneğindeki anlamından uzaklaşır. Bu iki kavram, akılcılığın dünyası ve mitosun dünyası arasında duran ve dişil geleneğin muhafızlarından olan Amaia'nın halası Engrasi aracılığıyla kadın cinsiyle özdeşleştirilip yüceltilir. İlk olarak erkek yazarlı polisiye romanlarda ortaya çıkan, daha sonra kadın yazarlı polisiye romanlarla sürdürülen, erkeği baştan çıkarıp tehlikeye sokan ve ölümle cezalandırılan femme fatale kadın stereotipi, polisiye roman geleneğinde süregelen anlamının dışına çıkarak yine türün cinsiyetçi yapısını kıran noktalardan biri olur. Femme fatale kadın, Baztán Üçlemesi’nde ataerkinin kendi eliyle yarattığı bir canavar olarak yansıtılır ve ölümle cezalandırılmaz. Bask mitolojisinde dişi tanrıça Mari’nin yardımcıları olduğuna ve femme fatale özellikler taşıdığına inanılan lamia, belagile ve sorgiñalar üzerinden de bu stereotip yeniden anlamlandırılır. Bu anlamlandırmayla birlikte anaerkilliğin izlerini silmeye çalışan ataerkil toplumun efsane ve mit gibi kültürü şekillendiren bütün kaynaklarda kendi çıarlarını koruyacak şekilde betimledikleri kadın kimliği ters yüz edilir. Sonuç olarak İspanyol edebiyatında Baztán Üçlemesìyle polisiye roman türünün cinsiyetçi yapısı kırılır ve tür, ekofeminist bir yaklaşımla yeniden yazıma uğrar.

Ortaya çıkışından beri kadınlar için uygun olup olmadığı tartışılan polisiye roman türü, günümüzde açık bir şekilde oluşturduğu dişil anlatı yapıları ve sahip olduğu feminist siyasi gündemle tartışmaya

RumeliDE Dil ve Edebiyat Araşttrmaları Dergisi Osmanağa Mahallesi, Mürver Çiçeği Sokak, No:14/8 Kadıköy - ÍSTANBUL / TÜRKIYE 34714 e-posta: editor@rumelide.com tel: +90 $5057958124,+902167730616$
Address

RumeliDE Journal of Language and Literature Studies

Osmanağa Mahallesi, Mürver Çiçeği Sokak, No:14/8

Kadıköy - ISTANBUL / TURKEY 34714

e-mail: editor@rumelide.com,

phone: +90 5057958124 , +90 2167730616 
son noktayı koymaktadır. Bugün polisiye edebiyat, politik ve toplumsal bir hareket olan feminizmle birlikte kendi içinde büyük değişimler yaşarken aynı zamanda barındırdığı feminist politikayla kadın okuyuculara önemli mesajlar iletmekte ve toplumsal bilince katkı sağlamaktadır. Özellikle türün, kimliğin sabit değişmezlik fikrini sorgulamaya açarak düalist düşünce sistemine karşı geliştirmekte olduğu eleştirel tutum, gelecek adına ümit vericidir.

\section{Kaynakça}

Aranzadi, J. (1981). Mari, Melusina y los orígenes míticos de los señores de Vizcaya. Los Cuadernos del Norte, 2/5, 2-8.

Arenas, P. (2015). Dolores Redondo: "No me gustan nada las mujeres que lo tienen todo muy claro". 20 Minutos. Erişim adresi: https://www.20minutos.es/noticia/2374254/o/entrevista-doloresredondo/trilogia-baztan/el-guardian-invisible-cine/

Barandiaran, J. M. de. (2014). Mitología Vasca. Donastia: Editorial Txertoa.

Bedore, P. (2008). Queer Investigations: Foxy Ladies and Dandy Detectives in American Dime Novels. Studies in Popular Culture, 31/1, 19-38.

Berktay, F. (2010). Tarihin Cinsiyeti. İstanbul: Metis.

Ceruti, M. C. (2011). Montañas sagradas en el Paīs Vasco y su mitologia. Mitológicas, XXVI, 29-42.

Checa S., Cid del Prado R., S. (2003). Nueva Masculinidad: Identidad, Necesidades Humanas y Paz. Asparkia: Investigació Feminista, 14, 33-43.

Demir, M. (2013). Çevre Olarak Konumlandırılmış Kadını ve Doğayı Birlikte Düşünmek: Ekofeminizm. Doğu Batı Düşünce Dergisi, 63, 11-44.

Donovan, J. (2016). Feminist Teori: Entelektüel Gelenekler. (Çev. A. Bora, M. A. Gevrek, F. Sayllan). İstanbul: İletişim.

Ehrenreich, B. (1987). Cadılar, Büyücüler ve Hemşireler. (Çev. E. Uğur). İstanbul: Kavram.

Estés. C. P. (2020). Kurtlarla Koşan Kadınlar: Vahşi Kadın Arketipine Dair Mit ve Öyküler. (Çev. H. Atalay). İstanbul: Ayrıntı.

Fetterley, J. (1978). The Resisting Reader: A Feminist Approach to American Fiction. Indiana University Press.

Gaard, G. (2001). Women, Water Energy: An Ecofeminist Approach. Organization\&Environment, $14 / 2,157-172$.

Gilbert, S., Gubar, S. (2016). Tavan Arasındaki Deli Kadın. (Çev. N. Sakman). İstanbul: Aylak Adam.

Griffin, S. (1978). Woman and Nature: The Roaring Inside Her. USA: Harper\&Row Publishers.

Heilbrun, C. G. (2002). The New Female Detective. Yale Journal of Law and Feminism, 14/2, 419-428.

Henningsen, G. (1978). Alonso de Salazar Frias: Ese famoso inquisidor desconocido. Homenaje a Julio Caro Baroja. Madrid: Centro de Investigaciones Sociológicos, 581-586.

Kümbet, P. (2012). Ekofeminizm: Kadın, Kimlik ve Doğa. Ekoeleştiri: Çevre ve Edebiyat. (Ed. Serpil Oppermann). Ankara: Phoenix.

Morcillo, C. (2011). La Guardia Civil investiga el asesinato de una bebé a manos de una secta hace 30 años. $A B C$. Erişim adresi: https://www.abc.es/deportes/abcp-guardia-civil-investiga-asesinato201110300000_noticia.html?ref=https:\%2F\%2Fwww.google.com\%2F

Munt, S. R. (1994). Murder by the Book? Feminism and the Crime Novel. London: Routledge.

Ortiz Osés, A. (1984). La diosa vasca en su contexto antropologico. Revista de Ciencias, 1, 7-16.

Özdemir, H., Aydemir, D. (2019). Ekolojik Yaklaşımlı Feminizm/Ekofeminizm Üzerine Genel Bir Değerlendirme: Kavramsal Analizi, Tarihi Süreci ve Türleri. Akdeniz Kadın Çalışmaları ve Toplumsal Cinsiyet Dergisi, 2, 261-278.

Adres

RumeliDE Dil ve Edebiyat Araşturmaları Dergisi Osmanağa Mahallesi, Mürver Cicçeği Sokak, No:14/8 Kadıköy - İSTANBUL / TÜRKIYE 34714 e-posta: editor@rumelide.com tel: +90 $5057958124,+902167730616$
Address

RumeliDE Journal of Language and Literature Studies

Osmanağa Mahallesi, Mürver Çiçeği Sokak, No:14/8

Kadıköy - ISTANBUL / TURKEY 34714

e-mail: editor@rumelide.com,

phone: +90 505 7958124, +90 2167730616 
Panek, L. L. (2003). Post-war American Police Fiction. The Cambridge Companion to Crime Fiction. (Ed. M. Priestman). Cambridge: Cambridge University Press, 155-171.

Panizo Büyükkoyuncu, M. A. (2009). Romantic Discourse and Feminine Subjectivity in Gertrudis Gómez de Avellanada's La Dama de Amboto (The Dame of Mt. Amboto). Litera, 22/1, 1-15.

Plumwood, V. (2020). Feminizm ve Doğaya Hükmetmek. (Çev. B. Ertür). İstanbul: Metis.

Reddy, M. T. (2003). Women Detectives. The Cambridge Companion to Crime Fiction. (Ed. M. Priestman). Cambridge University Press, 191-207.

Redondo, D. (2017). El Guardián Invisible. Barcelona: Editorial Planeta.

Redondo, D. (2016). Legado en los Huesos. Barcelona: Editorial Planeta.

Redondo, D. (2016b). Ofrenda a la Tormenta. Barcelona: Editorial Planeta.

Sainz Borgo, K. (2019). Dolores Redondo: Los márgenes de la novela negra me quedan pequeños para contar lo que quiero contar. Zenda. Erişim adresi: https://www.zendalibros.com/entrevistadolores-redondo-lado-norte-corazon/

Tong, R. (2006). Feminist Düşünce. (Çev. Z. Cirhinlioğlu). İstanbul: Gündoğan.

Uçar Özbirinci, P. (2012). Dünya Kadına Karşı. Ankara: Eflatun.

Valle Murga, M. T. Del. (1982). Los estudios sobre la mujer en la antropología vasca. Zainak. Cuadernos de Antropologia-Etnografia, 1, 123-134.

Verdú Delgado, A. D. (2012). La desaparición de las diosas como metáfora de la pérdida de autoridad de las mujeres. Feminismo/s, 20, 63-80.

Yılmaz Aslantürk, A. (2018). Çevrenin Siyasallaşmasında Kadın ve Doğanın Dönüşümü: Ekofeminizm. Social Science Development Journal, 3/11, 312-324. 